\title{
変動繰返し圧縮荷重下におけるコンクリートの 疲労寿命に関寸る研究
}

西林新蔵* 矢 村 潔* 井上正一

\section{Fatigue Life of Concrete under Varying Repeated Compressive Load}

\author{
by
}

\author{
Sinzo Nishibayashi, Kiyoshi Yamura and Shoich Inoue \\ (Faculty of Engineering, Tottori University, Tottori)
}

\begin{abstract}
In order to investigate the fatigue life of concrete under varying repeated load, several stress fatigue tests were performed. In these tests, concrete cylinder specimens were subjected to the repeated load in which load levels were selected as to be between a constant minimum stress level and five different maximum stress level $S_{\jmath},(72 \sim 82$ percent of the ultimate static strength at each interval of $2.5 \%$ ). The triangular-, normal-, uniform-, and exponential-distributions were used as the shape of the stress block for the varying repeated load. The order of the applied maximum stress level was selected at random.

From the experimental results, it can be concluded as follows. (1). At each test condition, the sun of cycles ratio follows a logarithmic normal distribution. (2). Miner's rule may possibly be applied to predict the fatigue life under varying repeated load in which the magnitude of stress is changed quite very frequently.

キー・ワード: 疲労, 累積繰返し回数比, 疲労寿命, マイナー則

(Received July 2, 1982)
\end{abstract}

\section{1 緒言}

コンクリート部材や構造物の設計を合理的に行い, かつ耐用期間中に構造物がその機能を十分に発揮する ことを保証するためには，コンクリートの疲労特性を 明確化し，これを設計に的確に反映させることが非常 に重要である.

本研究は，ランダム荷重を受けるコンクリートの疲 学特性, とりわけ実構造物の使用限界汇関連する疲労 寿命を推定する方法を確立することを目的として行っ たものである，年のうち，2 段階応力試験の結果につ いては先に報告したので，ここでは，外力荷重のパタ ーンとして，応カレベルとその作用頻度を表すモデル に数種の代表的な確率密度関数を用いた多段階重複応 力（以下変動応力と称する）について試験を実施し， これらの試験で得られた疲労寿命の結果を, 累積繰返 乙回数比の概念を用いて評価し，その確率分布特性を 明確にしている.ささら，一定応力試験の結果から， ランダム荷重下の疲労寿命を推定しうる可能性を検討 し，併せてマイナー則の適用性とその適用限界につい てはランダム荷重の性質や限界状態設計法との関連に

†原稿受理 昭和 57 年 7 月 2 日

* 正. 会 員 鳥取大学工学部 鳥取市湖山町
おいて若干の考察を加光ている.

\section{$2 \cdot 1$ 使用材料と供試体}

\section{2 実 験 概 要}

セメントは普通ポルトランドセメント，粗骨材には 高梘産碎石（最大寸法 $15 \mathrm{~mm}$, 比重 2.69) を, 細骨 材には野州川産川砂（比重 2.59, F. M. =2.58）を使 用した。コンクリートの配合条件は，28 日目標強度 $34 \mathrm{MPa}$, スランプ $5 \pm 1 \mathrm{~cm}$, 空気量 $5 \%, s / a=46 \%$ で, 単位セメント量 $280 \mathrm{~kg}$, 水セメント比 $61 \%$ の配 合が試練りによって決定された.

供試体は $\phi 7.5 \times 15 \mathrm{~cm}$ の円柱で, 28 日間標準養生 を施し，以後疲労試験実施（材令 120 日以上）まで実 験室内に保存した。

\section{$2 \cdot 2$ 試験方法}

疲労試験は, 一定応力試験と変動応力試験からなっ ている.これらの試験は, 容量 25 トンの電気油圧式当 一ボ機構を有する疲学試験機（MTS 社製）を用い, 繰返乙載荷速度 $5 \mathrm{~Hz}$, 荷重と時間 との関係は正弦波 形のもとで行った．設定した上限応力比（ $S$ ：以下応 力比と称す）は, 試験開始前に行った各打設バッチご と8 本の供試体の关れぞれの平均圧縮強度 $\left(\bar{\sigma}_{c}=40.1\right.$ $\sim 42.6 \mathrm{MPa}$, 変動係数の最大值 $3.4 \%$ ）飞対する百分 
率で選び，下限応力比はすべて $\bar{\sigma}_{c}$ の10\%とした.

変動応力試験は, 応力比 $(S)$ とその応力比が作用 する頻度 $\left(p^{*}(S)\right)$ の関係を表すモデルとして, Fig. 1 に示すようなとストグラムを採用し，これを1応力ブ ロックとする載荷を行った. Fig. 1 に示す分布モデル のらち, 三角形 (略号 $T$ ) 分布は, 実橋の 1 等橋にお いて疲労損傷に大きな影響を及ぼすと考えられる11卜 ン以上の輪荷重の頻度結果が皃ぼ三角形分布を呈する こと, 正規 (略号 $N$ ) 分布は, 車線内に打ける車両の 車輪通過位置の分布が正規分布を示すので, 荷重一定 のもとで橋軸直角方向の所定断面に批けるモーメント が正規分布になるとの仮定から設定した．また，指数 （略号 $F$ と E）分布モデルは, 海洋に拈ける波高とそ の生起する回数の関係が片対数紙上で直線になり，さ らに波高と構造物内の応力との間には線形関係が成立 するといら事実を参考にして選定した。 その他の分布 モデル三角形（略号 $B$ ) と矩形（略号 $U$ ) は, 応力比 の作用頻度が疲労寿命に及ぼす影響を検討するために 選んだものである。
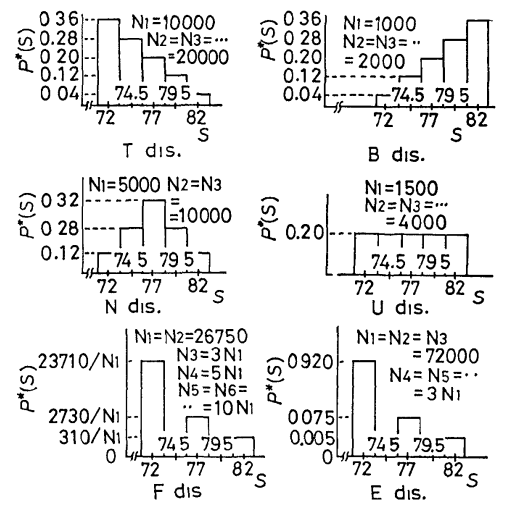

Fig. 1. Details of varying stress fatigue tests $(S$ : Stress level, $p^{*}(S)$ : Frequency, $T, B$ dis.: Triangular distribution, $N$ dis : Normal distribution, $U$ dis.: Uniform distribution, $F, E$ dis.: Exponential distribution.

応力ブロック内の荷重順序 $j(j=1, \cdots, 5)$ 番目の 応力比 $\left(S_{\jmath}\right)$ は, 設定応力比 $(S=1172, \cdots$, (5) $82 \%)$ に番号を付け, 各供試体ごとに(1)〜(5)までの一様乱数 を発生させ， 5 けたの数字の順列を作ることによって 決定した.つぎに, 各応力比 $\left(S=S_{\jmath}\right)$ に括汀る載荷回 数 $n_{\imath}\left(S_{\jmath}\right)$ は, $i(i=1, \cdots, u)$ 番目の応力ブロック内 の総載荷回数 $\left(N_{i}\right)$ を与光ることによって, $n_{\imath}\left(S_{\jmath}\right)=$ $N_{\imath} \times p^{*}\left(S=S_{\jmath}\right)$ で算定される. 試験は, すべての設定 応力比を少くとも 1 回は受けるよう $N_{1}$ に小さな值を 選び, 1 番目の応力ブロック内の $n_{1}\left(S_{1}\right)$ から順次載 荷し, $u$ 番目の応力ブロック内の第 $k$ 番目の応力比で 供試体が破壊するときの回数 $n_{u}\left(S_{k}\right)$ を測定した.

\section{3 結果と考察}

\section{$3 \cdot 1$ 一定応力試験}

一定応力試験によるコンクリートの疲労寿命の分布 形は, 対数正規分布に良く適合することがすでに認め られている.

Fig. 2 は, 各応力比に打将疲労寿命 $(N)$ と式(1) から求めた生存確率 $(p)$ の関係を, 対数正規確率紙 上に図示したものである.

$$
p=1-r /(l+1), t \equiv \phi^{-1}(p)
$$

ここに, $l$ は同一試験条件に用いた供試体総数, $r$ は順序統計量で, 疲労寿命 $(N)$ あるいは後記の $M$ を 小さい順に並べたときの序数である．また， $t$ は正規 確率密度関数の対称軸からの距離で, 任意のpの值に 対して標準正規積分表 $(p=\phi(t))$ より求められる.

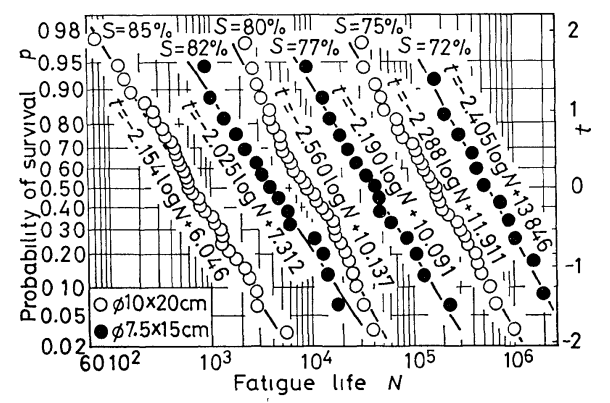

Fig. 2. $P-N$ diagram $\left(\phi 10 \times 20 \mathrm{~cm}, \quad \bar{\sigma}_{c}=25 \mathrm{MPa}\right)^{1)}$.

図より,プロット点はほぼ直線上にあり, 各応力比 ごとの疲労寿命の分布は, 式(2)で表される対数正規分 布に従らとみなせる。

$$
t=A \log N+B
$$

上式で, $t=0(p=0.5)$ を代入して求めた $N$ の值が 平均疲労寿命 $(\bar{N})$ となる. また, $\log N$ の平均值を $m(\log N)$ と, ばらつきを表す指標として $\log N$ の 標準偏差を採って $V(\log N)$ と表記すれば，それぞれ 次式で表され，式(2)を最小 2 乗法によって決定した Fig. 2 に付記した直線式から求息.

$$
\left.\begin{array}{l}
\bar{N}=10^{-B / A}, \quad m(\log N)=-B / A \\
V(\log N)=1 /|A|
\end{array}\right\}
$$

コンクリートの場合, 応力比 $(S)$ と平均疲労寿命 $(\bar{N})$ の関係を示す式として, 次式の形の $S-\bar{N}$ 線式が よく用いられる.

$$
S=A_{1} \log \bar{N}+B_{1}
$$

Fig. 3 に示す $S-\bar{N}$ 線式より，コンクリートの配合， 強度，供試体の寸法に関係なく, $S-\bar{N}$ 線式は同一の

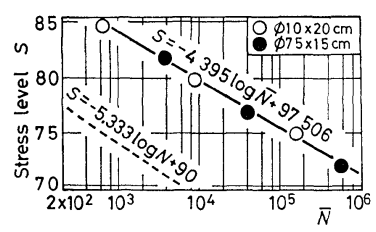

Fig. 3. $S-\bar{N}$ diagram 
式で表されるようである、な物，図中の破線は，土木 学会 “コンクリート構造の限界状態設計法試案” の基 礎となった $S$ N 線式を示したものである。これらの 式に, $\bar{N}, N=200$ 万回を外插した疲労強度は, 本研 究結果では69.8\%，土木学会式では $56.3 \%$ となる.

\section{$3 \cdot 2$ 変動応力試験}

Table I 飞変動応力試験の結果の一例を示す. 表中, $r$ : 順序統計量, $p, t$ : 生存確率と標準正規変量で それぞれ式(1)上り求まる． $S_{j}$ ：荷重順序 $j$ 番目の応力 比, $u, S_{k}$ : 破壊時の応力ブロック数と応力比, $\sum n$ : 破壊に至るまでの総繰返し回数である. M は累積繰返 乙回数比で, $u=1, j=2$ の 2 段応力試験においては 式(5)で定義したが，ここでは変動応力試検の $M$ を式(6) で定義して疲労寿命を評価することにする。

$$
\begin{aligned}
& M=n_{1} / \bar{N}_{1}+n_{2} / \bar{N}_{2}, \quad R_{1}=n_{1} / \bar{N}_{1} \\
& M=\sum_{\imath=1}^{u-1}\left(\sum_{\jmath=1}^{5} \frac{n_{\imath}\left(S_{\jmath}\right)}{\bar{N}\left(S_{\jmath}\right)}\right)+\sum_{\jmath=1}^{k} \frac{n_{u}\left(S_{\jmath}\right)}{\bar{N}\left(S_{\jmath}\right)}
\end{aligned}
$$

ここに, $\bar{N}_{1}, \bar{N}_{2}$ は, 一定応力試験で得られた応力 比 $S=S_{1}, S_{2}$ に打ける平均疲労寿命で Fig. 3 中のプロ ット点の值を用いる. $n_{1}, n_{2}$ は, それぞれの応力比の 載荷回数, さらに $R_{1}$ は先行応力比 $S=S_{1}$ に怙ける繰 返し回数比である. また, $\bar{N}\left(S_{\jmath}\right)$ は応力比 $S=S$, 飞拉 ける疲労寿命で $S-\bar{N}$ 線式に $S=S$ をを代入して求めた $\bar{N}$ の值を用いる. Table 中の $M, M_{1}$ は, Fig. 3 飞示 した $S-\bar{N}$ 線式拉よび土木学会式で $N を \bar{N}$ と表記した $S-\bar{N}$ 線式を用いて算定した值である。
$3 \cdot 2 \cdot 1$ 故障率と疲労破壊の特性 コンクリート の疲労破壊の機構を考察するため，ここでは器機の寿 命を検討する際によく用いられている故障率の概念を 適用する，故障率は，ある時間 $T$ まで破壊せず，これ に続く単位時間内に破壊する割合で定義され，式(7)で 表される。

$$
\lambda(T)=-\frac{d \log p}{d T}
$$

式(5)，(6)の $M$ をTで置き換えると， $\lambda(M)$ は $M$ をパ ラメータとする故障率になる.

Fig. 4 は，pとMの関係を各試験条件ごとに図示し たものである. 変動応力試験のプロット点の傾さは, $M \fallingdotseq 2$ を境にややゆるやかになる傾向があるが, 全般 的には一定応力試験の場合と同様にほぼ一定とみなせ る. 一方, 2 段階応力試験の故障率は, 先行応力比に おける繰返し回数比，すなわち，荷重の大きさを変化 させた点 $M=R_{1}$ を境に, 先行応力比 $\left(S_{1}\right)$ が後行応 力比 $\left(S_{2}\right)$ より 小さい場合には減少, $S_{1}$ が $S_{2}$ より も大きい場合には増大し, 最終的には $M$ の増加に伴っ て減少する傾向を示す。この場合, 疲労寿命を推定す るためのパラメータMの検討に際しては, 故障率が荷 重順序の相違によって影響されることを考慮する必要 がある. 一方, 本研究のよらなランダム荷重下におい ては，故障率はほぼ一定值を示すので，荷重順序の影 響を考慮する必要はなく, Mで疲労寿命の推定が行光

\begin{tabular}{|c|c|c|c|c|c|c|c|c|c|c|c|c|c|c|}
\hline \multirow{3}{*}{$r$} & \multirow{3}{*}{$P$} & \multirow{3}{*}{$t$} & \multicolumn{6}{|c|}{$B$ distribution } & \multicolumn{4}{|c|}{$E$ distribution } & \multirow{3}{*}{$M$} & \multirow{3}{*}{$M_{1}$} \\
\hline & & & \multirow{2}{*}{$\begin{array}{c}\text { OS } \\
\text { Sر }\end{array}$} & \multicolumn{3}{|c|}{ At failure } & \multirow{2}{*}{$M$} & \multirow{2}{*}{$M_{1}$} & \multirow{2}{*}{$\begin{array}{c}\text { O S } \\
S_{J}\end{array}$} & \multicolumn{3}{|c|}{ At failure } & & \\
\hline & & & & $u$ & $s_{k}$ & $\sum n$ & & & & $u$ & $S \kappa$ & $\sum n(\times 10)$ & & \\
\hline 1 & 0952 & 1665 & 34215 & 2 & 82 & 2480 & 025 & 29 & 827772 & 1 & 72 & 2181 & 025 & 38 \\
\hline 2 & 0905 & 1311 & 23451 & 2 & 82 & 2900 & 040 & 45 & 777282 & 2 & 77 & 7339 & 036 & 64 \\
\hline 3 & 0857 & 1067 & 53124 & 3 & 82 & 3390 & 052 & 58 & 778272 & 2 & 77 & 7634 & 042 & 75 \\
\hline 4 & 0810 & 0878 & 45312 & 3 & 82 & 3880 & 054 & 58 & 777282 & 2 & 72 & 10426 & 049 & 90 \\
\hline 5 & 0762 & 0713 & 15432 & 4 & 82 & 5220 & 071 & 80 & 777282 & 2 & 72 & 11518 & 050 & 95 \\
\hline 6 & 0714 & 0565 & 25413 & 4 & 82 & 5490 & 074 & 84 & 827772 & 2 & 72 & 12486 & 062 & 110 \\
\hline 7 & 0667 & 0432 & 51342 & 5 & 82 & 7010 & 094 & 106 & 727782 & 3 & 72 & 17484 & 0.70 & 125 \\
\hline 8 & 0619 & 0303 & 24135 & 5 & 79.5 & 7450 & 095 & 110 & 827772 & 3 & 82 & 14572 & 072 & 131 \\
\hline 9 & 0571 & 0179 & 54321 & 5 & 77 & 8400 & 118 & 135 & 778272 & 3 & 82 & 14958 & 082 & 143 \\
\hline 10 & 0524 & 0060 & 42153 & 6 & 82 & 10120 & 132 & 150 & 827772 & 3 & 72 & 15212 & 088 & 150 \\
\hline 11 & 0476 & -0060 & 51243 & 6 & 82 & 9720 & 142 & 159 & 727782 & 4 & 72 & 21729 & 098 & 177 \\
\hline 12 & 0429 & -0179 & 43521 & 7 & 82 & 12080 & 156 & 178 & $77 \quad 7282$ & 4 & 72 & 32752 & 148 & 276 \\
\hline 13 & 0381 & -0303 & 35241 & 8 & 795 & 14640 & 193 & 224 & 727782 & 4 & 77 & 42547 & 153 & 276 \\
\hline 14 & 0333 & -0432 & 25314 & 9 & 82 & 15730 & 2.16 & 243 & $77 \quad 7282$ & 4 & 72 & 39896 & 1.59 & 300 \\
\hline 15 & 0281 & -0565 & 13254 & 10 & 795 & 18490 & 251 & 282 & $\begin{array}{lll}77 & 82 & 72\end{array}$ & 4 & 72 & 26648 & 1.70 & 306 \\
\hline 16 & 0.238 & -0713 & 41523 & 13 & 82 & 24040 & 325 & 367 & 778272 & 4 & 72 & 41520 & 1.94 & 346 \\
\hline 17 & 0.190 & -0878 & 12345 & 14 & 77 & 25560 & 336 & 380 & 827772 & 5 & 72 & 59516 & 286 & 509 \\
\hline 18 & 0143 & -1067 & 52431 & 16 & 82 & 29590 & 406 & 458 & 727782 & 6 & 72 & 76546 & 313 & 580 \\
\hline 19 & 0095 & -1.311 & 32145 & 22 & 77 & 41310 & 550 & 623 & 728772 & 9 & 72 & 134483 & 597 & 1080 \\
\hline 20 & 0048 & -1665 & 13542 & 30 & 77 & 57220 & 765 & 864 & $77 \quad 8272$ & 10 & 72 & 189208 & 778 & 1390 \\
\hline
\end{tabular}
る可能性のめることを示している.

Table I. Results of varying stress fatigue test. 


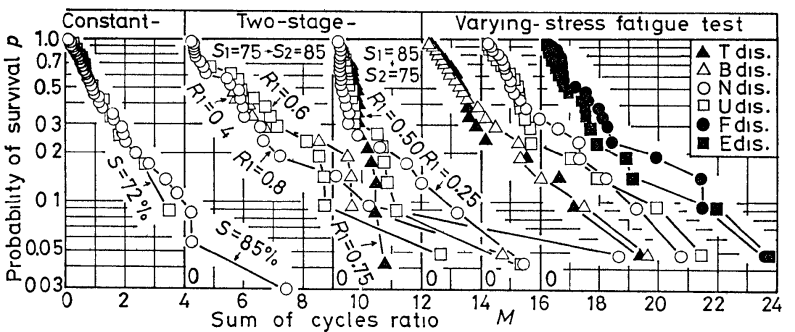

Fig. 4. $S-M$ diagram.

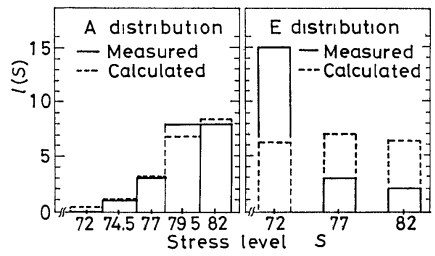

Fig. 5. Relationship between stress level $S$ and number of specimens broken at $S$.
つぎに, $M$ が疲労寿命の評価值として適切であるか ぞうかを供試体の破壊状況から考えてみよう。

Fig. 5 は, 変動応力試験に护ける設定応力比 $\left(S=S_{\jmath}\right)$ とその応力比で破壊した供試体数 $l(S)$ との関係の一 例を示したものである. 図中の計算值は，それぞれの 分布モデルに対し次式から算定したものである.

$$
l\left(S=S_{\jmath}\right)=l \times R_{\jmath} / \sum_{\jmath=1}^{5} R_{\jmath}
$$

ここに, $l$ は供試体総数， $R$, は第 1 応力ブロック 内の各応力比に和ける繰返し回数比で, 式(6)において $R_{\jmath}=n_{1}\left(S_{\jmath}\right) / \bar{N}\left(S_{\jmath}\right)$ と置いたものである.

図より，S=82,79.5\%の高応力比での 設定繰返 し 回数比 $\left(R_{j}\right)$ が大きく, $S=72,74.5 \%$ の低応力比の $R$, が小さな三角形, 正規, 矩形分布モデルの試験に 扣いては, 各応力比に戚ける供試体破壊個数は実験值 と計算值でほぼ等しくなる.このことは，上述したよ らな高応力比での損傷の程度の著しいモデルの場合, 応力比 $S=S, 1$ 回の載荷によって $1 / \bar{N}\left(S_{\jmath}\right)$ だけ損傷 し，以後の載荷に执いては，これらの和として疲労損 傷が進行していることを示唆している. 一方, 低応力 比での $R$, が比較的大きい指数分布モデルに打いては, 実験值と計算值との間に違いのあることが認められ る. この差異はFig. 4 と関連づけることによって定 性的に説明できる.すなわち， 2 段階応力試験の結果 に見られるように，低応力比から高応力比に移行した 直後の故障率は小さく, 高応力比から低応力比に変化 したとき故障率は大きくなっている．指数分布モデル に沶いては, 応力比の変化に伴ら故障率の影響が現れ, 供試体は高応力比で破壊しにくく，それに続く低応力 比で破壊しやすくなったものと推察される. 一方, 高 応力比での損傷の程度の大さいモデルの場合には, 低 応力比での載荷回数が比較的少いため, 高応力比から 低応力比へ移行するときの故障率の増加による影響を 受けず，供試体はそれに続くより高い応力比で破壊し たものと考觉られる. しかし, 本研究に打いては, 荷 重順序をランダムに選定し，応力比の大きさをかなり 頻繁に変化させたため, 各分布モデルの故障率には顕 著な差はなく，したがってランダム荷重を取扱ら場合 には, 疲労損傷は線形的に累積進行し, Mは疲労寿命
推定のパラメータとして適切なものであると解しても よいようである.

$3 \cdot \mathbf{2} \cdot 2$ 累積繰返し回数比 $(\boldsymbol{M})$ の分布形 式(7)に おいて $\lambda(T)$ が一定のとき，その分布形は指数分布で 表される.しかし $\lambda(M)$ は厳密には一定でなく，一定 応力試験の疲労寿命の分布形への適合性は対数正規分 布の方が指数分布よりも優れているよらである. した がって, ここでは, 変動応力試験に括けるMに対して, 次式で表される対数正規分布への当てはめを検討する ことにする.
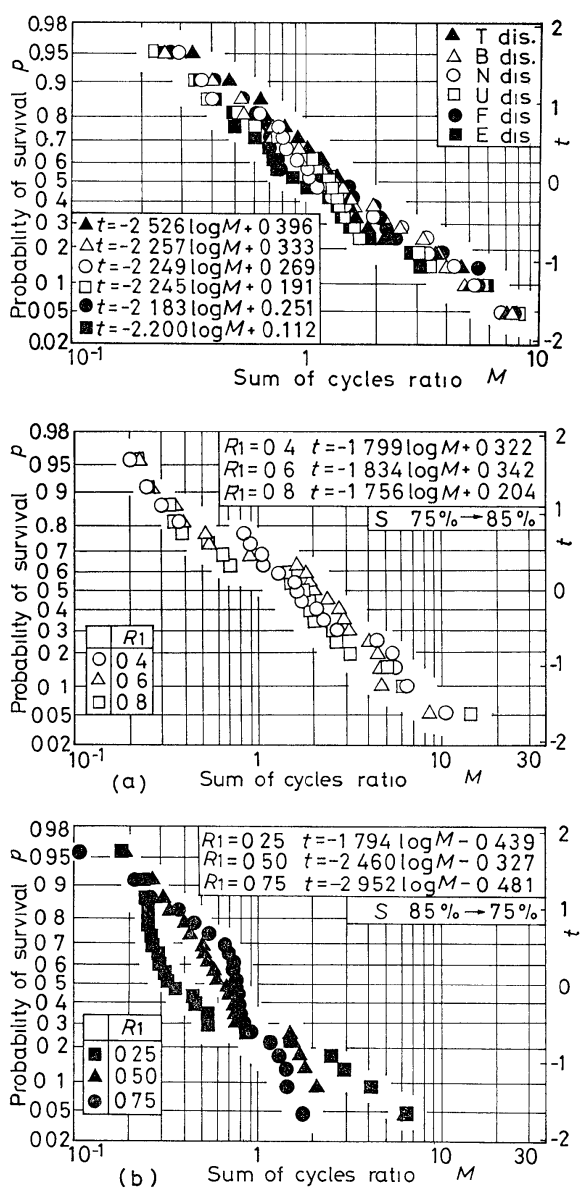

Fig. 6. $P-M$ diagram ((a), (b): Two-stage stress fatigue test) 


$$
t=A \log M+B
$$

Fig. 6 は, 生存確率 $p$ と $M$ との関係を, 各試験条件 ごとに対数正規確率紙上にプロットしたもので，図に は2 段階応力試験の結果も示している. また図中の直 線式は式(9)を最小 2 乗法によって決定したものである. いま, $M$ の分布がこれら直線式で与兄られる対数正規 分布に従うと仮定して $K-S$ 検定を行った. その結果， 各試験条件ごとのMの分布は有意水準 $20 \%$ で仮定した 対数正規分布に従らことが明らかとなった.

\section{$3 \cdot 2 \cdot 3$ 平均累積繰返し 回数比 $(\overline{\boldsymbol{M}})$ と標準偏差}

$\boldsymbol{V}(\log \boldsymbol{M}) \quad M$ 分布が式(9)で表されたとき， $t=0(p$ $=0.5)$ に相応する $M$ の值, すなわち, 平均累積繰返 し回数比 $(\bar{M}), \log M$ の平均 (期待) 值 $m(\log M)$ およびその標準偏差 $V(\log M)$ は次式(10)で与兄られ る.

$$
\begin{aligned}
& \bar{M}=10^{-B / A}, \quad m(\log M)=-B / A \\
& V(\log M)=1 /|A|
\end{aligned}
$$

一定応力試験に括いて, 疲労寿命 $N$ が式(2)で表され る対数正規分布に従らとき， $N$ を平均疲労寿命 $\bar{N} て ゙$ 除 すと, $M=N / \bar{N}$ となる. 両辺の対数を採れば

$$
\log M=\log N-m(\log N)
$$

となり，これより次式の関係が得られる。

$$
\begin{aligned}
& \bar{M}=1, m(\log M)=0 \\
& V(\log M)=V(\log N)=1 /|A|
\end{aligned}
$$

上式は, $\log N$ の標準偏差 $V(\log N)$ と $\log M$ の標 準偏差 $V(\log M)$ が等しく, $V(\log M)$ は先に決定 した Fig. 2 の直線式から算定できることを示してい る.

Fig.7，8は，式(10)，(11)から算定した $\bar{M}, V(\log M)$ を各試験条件ごとに示したものである．な抏，一定応 力試験の $\bar{M}$ の值は 2 段階応力試験 の $R_{1}=0$ 上にプロ ットしてある. 2 段階応力試験による $\bar{M}$ の值は 0.57 から 1.54 の範团にあり, この值は, 先行応力比 $\left(S_{1}\right)$ と後行応力比 $\left(S_{2}\right)$ の大小関係（荷重順序）に影響を受 け, $S_{1}$ が $S_{2}$ より小さい場合には 1 以上, $S_{1}$ が $S_{2}$ よ り大きい場合には 1 以下の值となる．荷重順序が同一 の場合, 先行応力比の繰返し数比 $\left(R_{1}\right)$ が $\bar{M}$ に及ぼす 影響は荷重順序の影響に比して小さいといえる．一方， 変動応力試験による $\bar{M}$ の值は 1.12 から 1.42 の範囲に ある.この場合， $\bar{M} の$ 範囲が 2 段階応力試験の場合よ

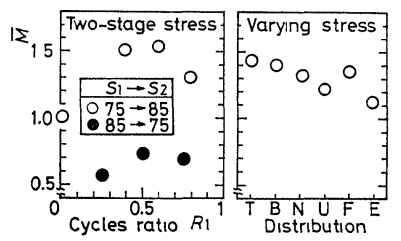

Fig. 7. Relationship between $\bar{M}$ and test condition.
りも小さいのは, 選定した分布モデルの相違, すなわ

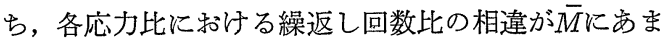
り影響を与えないこと, さらに応力比の大きさを順次 変えたため，2段階応力試験に見られたよらな荷重順 序の影響が現れにくくなったことによると考えられる。

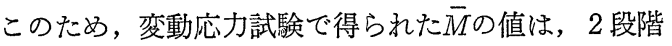
応力試験において荷重順序を変えて得られた $\bar{M} の$ 值の ほぼ中間的な值を示したものと推察される.

以上の結果より， $\vec{M} の$ 值はランダム荷重の性質によ って変化するので, $\bar{M}=1$ を破壊条件とするマイナー 則の疲労寿命の推定への適用は厳密には限界がある. しかし，荷重の大きさが短期間で変化するよらなラン ダム荷重下に扣いては, マイナー則によって疲労寿命 の推定が安全側で推定できるものと考えられる.

Fig. 8 に $\log M$ の標準偏差 $V(\log M)$ を示す. 図 より, 変動応力試験による $V(\log M)$ は0.40から0.46 の範囲にあり, その算術平均は 0.44 となる. この值は 一定応力試験に和ける $V(\log M)$ の範团0.39から0.46, その算術平均 0.44 と等しい值を示している. このこと は, ランダム荷重下に和けるMのばらつきは，一定応 力試験の $V(\log N)$ によって推定できる可能性のある ことを示唆している.

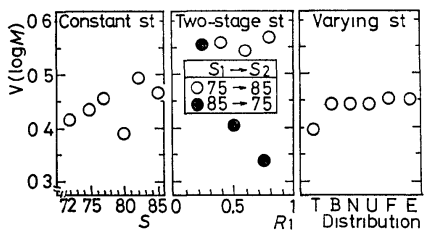

Fig. 8. Relationship between standard deviation and test condition.

\section{$3 \cdot 2 \cdot 4$ 累積繰返し回数比 $(\boldsymbol{M})$ の確率分布特性} コンクリート構造設計に捈いて， $M=1$ で設計した場 合, 破壊確率 $\left(p_{f}=1-p\right)$ はかなり大きくなる.した がって, 海洋コンクリート構造設計では $M=0.2$ を設 計用值として用いている. 一方, 土木学会限界状態設 計法試案では, 式(6)の $\bar{N}\left(S_{\jmath}\right)$ に Fig. 3 において破線 で示したよらな $S-N$ 線式から算定した值を用い，安 全性を確保しようとしている.

Table II は, Fig. 6 の直線式に $M=0.2$ を代入し て求めた破壊確率 $\left(p_{f}\right)$, および 変動応力, 2 段階応 力試験に土木学会の $S-N$ 線式を適用し， $\bar{M}, \quad V(\log$ $M), M=1$ に打ける $p_{f}$ のオーダを算定したもので ある.

表より，土木学会式に基づいて算定した $\bar{M} の$ 值は， 本実験室より求めた $\bar{M}$ (Fig. 7) の100倍程度の值を示 し， $\bar{M}$ は $M$ を評価する際に用いる $S-\bar{N}$ 線式の 違いに よって大さく変わることがわかる. 一方, $V(\log M)$ は $\bar{M}$ の值に比べてきわめて小さく $S-\bar{N}$ 線式の違い 
Table II. Results of regression analysis.

\begin{tabular}{|c|c|c|c|c|c|c|c|c|}
\hline \multirow{2}{*}{ Test } & \multirow{2}{*}{\multicolumn{2}{|c|}{ Distribution }} & $M=0.2$ & \multicolumn{2}{|c|}{$t=A \log M+B$} & \multirow{2}{*}{$\bar{M}$} & \multirow{2}{*}{$V(\log M)$} & \multirow{2}{*}{$\begin{array}{c}M=1 \\
P_{f}\end{array}$} \\
\hline & & & $P_{f}$ & $-A$ & $B$ & & & \\
\hline \multirow{6}{*}{ Varying st. } & \multicolumn{2}{|c|}{$T$} & 0.02 & 2.514 & 5.738 & 191 & 0.40 & $10^{-9}$ \\
\hline & \multicolumn{2}{|c|}{$B$} & 0.03 & 2.246 & 4.986 & 159 & 0.44 & $10^{-7}$ \\
\hline & \multicolumn{2}{|c|}{$N$} & 0.03 & 2.235 & 4.969 & 167 & 0.45 & $10^{-7}$ \\
\hline & \multicolumn{2}{|c|}{$U$} & 0.04 & 2.235 & 4.806 & 141 & 0.45 & $10^{-7}$ \\
\hline & \multirow{2}{*}{\multicolumn{2}{|c|}{$\begin{array}{l}F \\
E\end{array}$}} & 0.03 & 2.172 & 5.074 & 217 & 0.46 & $10^{-7}$ \\
\hline & & & 0.05 & 2.160 & 4.974 & 201 & 0.46 & $10^{-7}$ \\
\hline \multirow{7}{*}{ Two-stage st. } & $S$ & $R_{1}$ & $P_{f}$ & $-A$ & $B$ & $\bar{M}$ & $V(\log M)$ & $P_{f}$ \\
\hline & $S_{1}=75$ & 0.4 & 0.06 & 2.727 & 6.227 & 192 & 0.37 & $10^{-10}$ \\
\hline & & 0.6 & 0.05 & 2.904 & 6.794 & 219 & 0.34 & $10^{-11}$ \\
\hline & $S_{2}=85$ & 08 & 0.08 & 2.577 & 6.015 & 216 & 0.39 & $10^{-10}$ \\
\hline & $S_{1}=75$ & 0.25 & 0.21 & 1.335 & 2.486 & 73 & 0.75 & $10^{-3}$ \\
\hline & & 0.50 & 0.08 & 1.648 & 3.163 & 83 & 0.61 & $10^{-4}$ \\
\hline & $S_{2} \stackrel{\downarrow}{=} 85$ & 0.75 & 0.06 & 2.206 & 3.951 & 61 & 0.45 & $10^{-5}$ \\
\hline
\end{tabular}

によってもほとんど変化しないささらに，これらの結 果より，最も危険なランダム荷重の組合せは，いず れの $S-\bar{N}$ 線式から評価しても先行応力比が 後行応力 比よりも大きな 2 段階応力試験で得られている.この 場合, 土木学会の試案に基づいた破壊確率は, 強度の 特性值を決定するために一般に用いられている非超過 確率 $5 \%$ と同程度の值となっている. しかし，一般的 なランダム荷重下に和いては，土木学会試案はかなり 小さな破壊確率を想定していることになる.

\section{4 結 論}

本研究は, 変動繰返し荷重下に打けるコンクリート の圧縮疲労特性を把握することを目的として行ったも のである. 本研究の範围内で明らかになったことを列 挙し，結論とする.

（1）累積繰返し回数比で評価した故障率は，一定応 力, 変動応力試験のいずれに拉いてもほぼ一定值を示 し，疲労損傷は線形的に進行すると考兄られる.

（2）一定， 2 段階, 変動の各応力試験に和ける累積 繰返し回数比の分布は対数正規分布に従う.

（3）変動応力試験で得られた平均累積繰返し回数比 $(\bar{M})$ は， 2 段階応力試験に打いて荷重順序の違いで

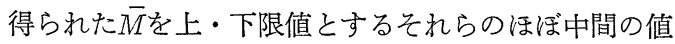
を採る. 一方, 累積繰返し回数比の対数の標準偏差は, 一定応力試験の場合とほほ等しい值を採る.

（4）荷重の大きさが順次変化するようなランダム荷
重下のコンクリートの疲労寿命の推定に，マイナー則 は安全側で適用できるものと考觉られる.

（5）平均累積繰返し回数比の值は, 累積繰返し回数 比（M)を評価する際の $S-\bar{N}$ 線式の違いによって大き く変化するが, 対数で表した $M の$ 標準偏差の変化はき わめて小さい。

本研究は, 著者の一人に交付された文部省科学研究 費による成果の一部であり，また著者の一人が京都大 学に流動研究員として派遣されている際に行った研究 の一部をも含んでいる.ここに, 京都大学工学部・岡 田清教授をはじめ関係各位に深甚の謝意を表する次第 である.

\section{参 考 文 献}

1）西林新藏，阪田憲次，井上正一，材料， 31，1114(1982).

2）国広哲男，構造工学シンポジウム論文報告集，22(1976).

3）阪田憲次，木山英郎，西林新蔵，土木学会論文報告集, 198 (1972).

4）土木学会編，“コンクリート構造の限界状態設計法試案”, p. 17 (1981).

5）岡村弘行，板垣 浩，“強度の統計的取扱い”, p. 53 （1979）培風館

6）伊藤 学, 亀田弘行訳, “土木・建築のための確率統計 の基礎”, p.274 (1977) 丸善

7) F. D. Lydon, "Development in Concrete Technology1”, p. 132 (1977) Science Publishers Ltd. 